\title{
Dose-Response CuRVES OF Lolium multiflorum BiotyPes Resistant and Susceptible to Clethodim ${ }^{1}$
}

\author{
Curvas de Dose-Resposta de Biótipos de Lolium multiflorum Resistente e Suscetível ao \\ Herbicida Clethodim
}

VARGAS, L. ${ }^{2}$, FRAGA, D.S. ${ }^{3}$, AGOSTINETTO, D. ${ }^{3}$, MARIANI, F. ${ }^{3}$, DUARTE, T.V. ${ }^{3}$, and SILVA, B.M. ${ }^{3}$

\begin{abstract}
Chemical control with herbicides, especially glyphosate, is the main method used to control ryegrass. However, the repeated use of glyphosate has selected resistant ryegrass biotypes. Thus, the ACCase inhibitor herbicides have become the main alternative to control glyphosate-resistant biotypes, being widely used by farmers in Rio Grande do Sul. Repeated use of ACCase inhibitors, in turn, have selected ryegrass biotypes resistant to this herbicide mechanism. Thus, the objective of this study was to evaluate the response of ryegrass biotypes to different clethodim rates by dose-response curves. Increasing doses $(0$, $12,24,48,72,96,144$ and $192 \mathrm{~g}$ a.i. $\mathrm{ha}^{-1}$ ) of the herbicide clethodim were applied at the 3-4 ryegrass leaf stage. The variables control at 14 and 28 days after treatment (DAT) and shoot dry weight were evaluated. The data were fitted by nonlinear regression log-logistic and $\mathrm{C}_{50}$ and $\mathrm{GR}_{50}$ were calculated based on the equation. The resistance factor was obtained by the ratio of $\mathrm{C}_{50}$ or $\mathrm{GR}_{50}$ of the resistant biotype by matching the susceptible biotype. Based on the equation parameters, the doses of $\mathrm{GR}_{50} 64.7$ and $234.5 \mathrm{~g}$ a.i. ha ${ }^{-1}$ clethodim and $\mathrm{C}_{50} 11.2$ and $172.1 \mathrm{~g}$ a.i. ha ${ }^{-1}$ clethodim were obtained, at 28 DAT for the susceptible and resistant biotypes, respectively. The ryegrass biotype denominated Cotril is resistant to clethodim, being controlled with a dose 15.3 times greater than that of the susceptible biotype, and a $50 \%$ reduction of this biotype occurs with a dose 3.62 times higher than that of the susceptible one.
\end{abstract}

Keywords: ryegrass, cyclohexanodiones, herbicide resistance.

RESUMO - O controle químico com herbicidas, principalmente com uso de glyphosate, é o principal método de controle do azevém. Entretanto, o uso repetido de glyphosate selecionou biótipos de azevém resistentes. Os herbicidas inibidores da enzima ACCase passaram então a ser a principal alternativa de controle de biótipos resistentes ao glyphosate, sendo usados amplamente pelos produtores no Rio Grande do Sul. Contudo, o uso repetido dos inibidores da ACCase, por sua vez, selecionou biótipos de azevém resistentes a esse mecanismo herbicida. Diante disso, o objetivo deste trabalho foi avaliar a resposta de biótipos de azevém a diferentes doses do herbicida clethodim por meio de curvas de dose-resposta. Para isso, foram utilizadas doses crescentes do herbicida clethodim (0, 12, 24, 48, 72, 96, 144 e $192 \mathrm{~g}$ i.a. ha $\left.\mathrm{h}^{-1}\right)$ aplicadas no estádio de 3 a 4 folhas do azevém. As variáveis avaliadas foram controle aos 14 e 28 dias após aplicação dos tratamentos (DAT) e matéria seca da parte aérea. Os dados foram ajustados por regressão não linear log-logística e, a partir da equação, calcularam-se $C_{50}$ e $G R_{50}$. O fator de resistência foi obtido pela relação do $C_{50}$ ou $G R_{50}$ do biótipo resistente pelos correspondentes ao do biótipo suscetivel. A partir dos parâmetros da equação, foram obtidas as doses do $G_{50}$ de 64,7 e 234,5 g i.a. ha de clethodim e do $C_{50}$ de 11,2 e 172,1 g i.a. ha de clethodim, aos 28 DAT, para os biótipos suscetivel e resistente, respectivamente. O biótipo de azevém denominado Cotri1 é resistente ao clethodim, sendo controlado com uma dose 15,3 vezes maior que o respectivo suscetivel, e a redução de 50\% da matéria seca desse biótipo ocorre com uma dose 3,62 vezes maior, comparado ao suscetivel.

Palavras-chave: azevém, ciclohexanodionas, resistência a herbicidas.

Recebido para publicação em 27.8.2012 e aprovado em 26.10.2013.

2 EMBRAPA Trigo Researcher, Passo Fundo, Brasil, <leandro.vargas@embrapa.br>; ${ }^{3}$ Universidade Federal de Pelotas, Pelotas-RS, Brasil.

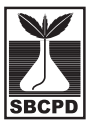

Planta Daninha, Viçosa-MG, v. 31, n. 4, p. 887-892, 2013 


\section{INTRODUCTION}

The use of herbicides is the main tool used to control crop-infesting weeds. As a result, resistant weed populations have developed in response to situations of intense herbicide use (Powles \& Yu, 2010).

In general, it can be said that the selection of herbicide-resistant weed populations is the result of misusing herbicides. Evidence suggests that herbicide resistance appears in a plant population because of the selection of preexisting resistant biotypes which find favorable conditions to multiply as a result of the selection pressure exerted by repeated applications of the same active ingredient (Silva \& Silva, 2007).

Among the species that have resistance issues due to the mechanism of change in the site of action is ryegrass (Lolium multiflorum), an outcrossing annual weed of the family Poaceae. It is adapted to low temperatures, and grows only in winter and spring (Kissmann, 2007). The species is well adapted to low and average fertility soils, and it has good response to fertilization and easy dispersion; therefore, it is considered as a weed, and it is present in almost all winter crops, orchards and vineyards in Southern Brazil (Vargas et al., 2007).

Ryegrass is usually controlled by the application of glyphosate. The repeated use of this herbicide caused the emergence of resistant biotypes in the state of Rio Grande do Sul (Roman et al., 2004). Thus, herbicides that inhibit enzyme Acetyl-coenzyme A carboxylase (ACCase) are used as an alternative control. A major ACCase-inhibiting herbicide is clethodim, a cyclohexanedione herbicide used for weed control in annual and perennial liliopsida at post-emergence which causes limited damage to non-target species (Cox \& Allen, 2008).

In most cases, weed resistance to herbicides causes changes to resistant biotypes compared to susceptible ones. One way to measure the level of resistance is using dose-response curves, which allow the identification of the dose of the herbicide that provides control of $50 \%$ of the population $\left(\mathrm{C}_{50}\right)$ or $50 \%$ reduction in the production of shoot dry weight $\left(\mathrm{GR}_{50}\right)$ (Christoffoleti, 2002). Knowledge of these variables yields the resistance factor (RF), which refers to how many times the dose required for controlling the resistant population is greater than the dose that causes the same effect on susceptible populations (Hall et al. 1998).

In recent years, there has been reduced efficiency control of ryegrass with the use of herbicides inhibiting the enzyme ACCase. This leads to believe that, in addition to resistance to inhibitors of 5enolpyruvylshikimate-3-phosphate synthase (EPSPS), this species is also resistant to ACCase inhibitors.

Thus, this study aims to evaluate the response of ryegrass biotypes to different doses of the herbicide clethodim by dose-response curves.

\section{MATERIAL AND METHODS}

In order to verify the resistance of ryegrass to the herbicide clethodim, an experiment was conducted in a greenhouse, between February and April 2010, in a completely randomized design with four replications. The ryegrass biotype identified as Cotri1, from the city of Carazinho, Rio Grande do Sul, was used. It initially survived field application with a dose of $400 \mathrm{~mL} \mathrm{ha}^{-1}$ of herbicide Select (96 g a.i. of clethodim) and was selected in a mass selection in the greenhouse, when a dose of $500 \mathrm{~mL} \mathrm{ha}^{-1}$ of herbicide Select was used (120 g a.i. of clethodim). The seeds came from plants of the biotype that survived the herbicide clethodim (Select at the dose of $500 \mathrm{~mL} \mathrm{ha}^{-1}$ ) in an assay at the greenhouse. They were later isolated in mini-greenhouses to avoid cross-pollination, and cultured until harvest. The control was comprised of seeds from plants from an area where clethodim had never been used; thus, they were considered to be susceptible.

The experimental units consisted of plastic pots with volumetric capacity of $500 \mathrm{~mL}$, which contained commercial substrate. Six seeds were sown per pot. Thinning was done later, when the plants had two leaves, which resulted in one plant per pot. 
To determine the values of $\mathrm{C}_{50}$ or $\mathrm{GR}_{50}$, compared to those of untreated plants, increasing doses of the herbicide clethodim were applied $(0,12,24,48,72,96,144$ and $192 \mathrm{~g}$ a.i. $\mathrm{ha}^{-1}$ ), and $96 \mathrm{~g} \mathrm{ha}^{-1}$ was the recommended dose for the control of ryegrass (Brasil, 2010). The treatments were applied at post-emergence, when the plants were at the three/four-leaf stage. A $\mathrm{CO}_{2}$-pressurized backpack sprayer outfitted with flat fan spray nozzles (110.015), and a spray volume equivalent to $165 \mathrm{~L} \mathrm{ha}^{-1}$. Adjuvant Lanzar at a dose of $0.5 \mathrm{v} / \mathrm{v}$. was also used.

The variables assessed were control and shoot dry weight. The control was visually assessed by two raters, at 14 and 28 days after treatment (DAT), using a percentage scale, where 0 represented no symptoms and 100, plant death (Frans et al., 1986).

The plants were harvested at 28 DAT to determine the production of shoot dry weight. For this purpose, the plant material was dried in a forced air oven at $60{ }^{\circ} \mathrm{C}$ until constant weight. Dry weight was fitted to percentage values by comparing the material obtained in the treatments with the herbicide to the weight obtained in the control, considered as $100 \%$.

Data were analyzed for normality (ShapiroWilk test) and then subjected to analysis of variance $(p \leq 0.05)$. If statistical significance was found, regression analysis was performed for the dose factor and, for the biotype factor, a comparison was made between $\mathrm{C}_{50}$ or $\mathrm{GR}_{50}$ values of the biotypes under study.

Regression analysis was performed by fitting the data to the equation for sigmoidal logistic regression, as follows:

$$
y=a /\left[1+\left(x / x_{0}\right)^{b}\right]
$$

where: $y=$ the percentage of control: $x=$ dose of the herbicide; $a, x_{0}$ and $b=$ parameters of the equation, where $a$ is the difference between the maximum and minimum points of the curve; $x_{0}$, the dose which provides $50 \%$ of the response of the variable; and $b$, the slope of the curve.

The values of $\mathrm{C}_{50}$ and $\mathrm{GR}_{50}$ yielded the $\mathrm{RF}$ for the susceptible and resistant biotypes of the species. To use the RF, the confidence interval $(\geq 0.95)$ had to be checked in the susceptible biotype, compared to the resistant one. The overlap of the confidence interval of the susceptible biotype compared to the resistant one indicates no significant difference between the $\mathrm{C}_{50}$ and $\mathrm{GR}_{50}$ values of the biotypes (Avila et al., 2005).

\section{RESULTS AND DISCUSSION}

There was interaction between biotype and dose for all variables. The Shapiro-Wilk test showed that the transformation of data was not required.

Ryegrass control by the herbicide clethodim was fitted to the equation for sigmoidal logistic regression at the two assessment periods; the values of the coefficient of determination $\left(\mathrm{R}^{2}\right)$ ranged from 0.97 to 0.99 , on average, for the susceptible and resistant biotypes, respectively, indicating satisfactory adjustment of the data to the model (Figures 1 and 2). From the equations, the values of $\mathrm{C}_{50}$ for the resistant and susceptible biotypes of ryegrass could be calculated.

The analysis of the charts of the control of the biotypes resistant and susceptible to the herbicide clethodim showed the behavior of sigmoidal curves in both ssessment periods (Figures 1 and 2). At 14 DAT, it was observed that for a control of $50 \%$ of the susceptible biotype, a dose of $35.5 \mathrm{~g}$ a.i. ha-1 of clethodim was needed, while the resistant biotype required a dose of $159.6 \mathrm{~g}$ a.i. ha-1 (Figure 1, Table 1).

The analysis of the chart of the control at 28 DAT showed that the dose of $11.2 \mathrm{~g}$ a.i. ha-1 of clethodim was enough to control $50 \%$ of the susceptible ryegrass biotype. The resistant biotype required a dose of $172.1 \mathrm{~g}$ a.i. ha ${ }^{-1}$ for the same control group (Figure 2 and Table 1). It was also observed that the dose of $72 \mathrm{~g}$ a.i. $\mathrm{ha}^{-1}$, corresponding to $75 \%$ of the registered dose of the product, was enough to control over $95 \%$ of the susceptible biotype. This biotype is $100 \%$ controlled by the registered dose of the product ( $96 \mathrm{~g}$ a.i. ha $\mathrm{ha}^{-1}$ ) while the dose of $192 \mathrm{~g}$ a.i. ha-1, which corresponds to $2 \mathrm{x}$ the registered dose, was the highest dose tested in this experiment, and it obtained control below $70 \%$ of the resistant biotype (Figure 2). 


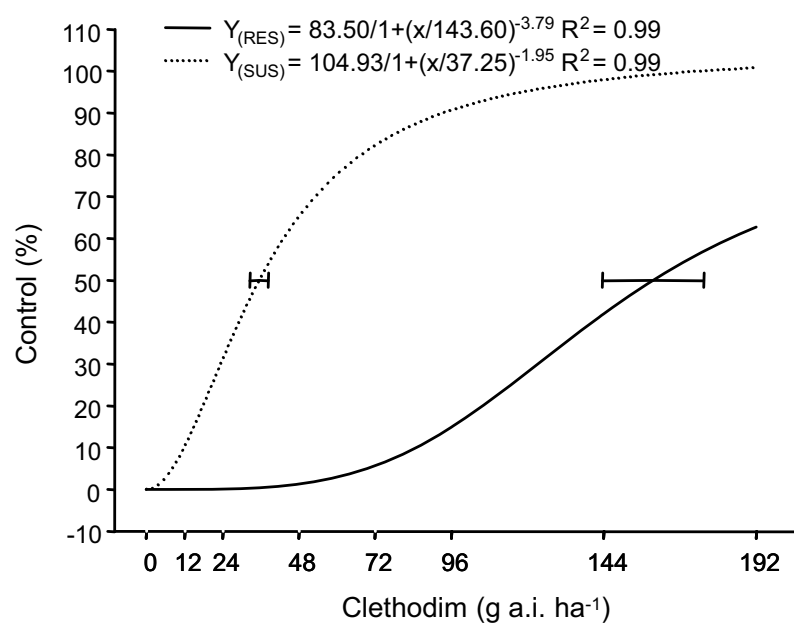

Error bars correspond to the confidence interval at $95 \%$ probability of error in the dose causing $50 \%$ toxicity in the plant.

Figure 1 - Control (\%) of resistant and susceptible Lolium multiflorum biotypes, due to the application of different doses of the herbicide clethodim, assessed at 14 days after treatment (DAT).

Based on the lack of overlap of the confidence interval (CI) of the susceptible biotype and the CI of the resistant biotype (Figures 1 and 2), it was possible to establish the FR for both assessment periods. In the last assessment period at $28 \mathrm{DAT}$, the FR value was 15.3 (Table 1), indicating that the dose of the herbicide clethodim required to promote $50 \%$ control of the resistant biotype is 15.3 times higher than the dose needed to produce the same effect on the susceptible biotype. Thus, according to the result obtained, it can be considered that the ryegrass biotype Cotri 1 is resistant to the herbicide clethodim.

ACCase inhibiting herbicides have been an alternative for controlling ryegrass biotypes resistant to glyphosate, but their repeated use has generated problems of resistance. In studies that evaluated the resistance of ryegrass to this mechanism of action, resistance to the herbicide clethodim was observed when it was applied at the dose of $96 \mathrm{~g}$ a.i. ha ${ }^{-1}$ (Rauch et al., 2010).

As for shoot dry weight, there was a decrease in sigmoidal curves as there was an increase in the dose of the herbicide clethodim for both biotypes, and such increase was more pronounced in the susceptible biotype. The variable was fitted to the equation for

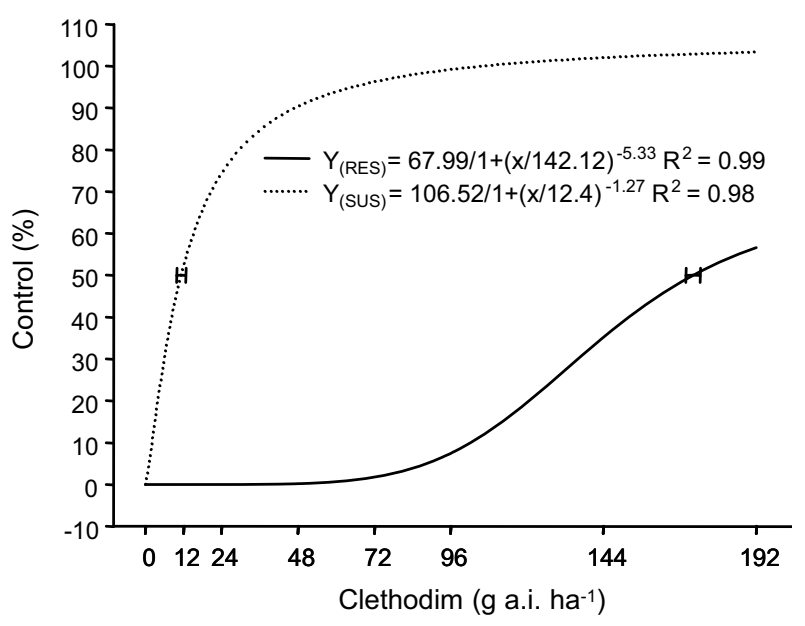

Error bars correspond to the confidence interval at 95\% probability of error of the dose causing $50 \%$ toxicity in the plant.

Figure 2 - Control (\%) of resistant and susceptible Lolium multiflorum biotypes, due to the application of different doses of the herbicide clethodim, assessed at 28 days after treatment (DAT).

sigmoidal logistic regression and the values of the coefficient of determination $\left(\mathrm{R}^{2}\right)$ ranged from 0.96 to 0.98 for the susceptible and resistant biotypes, respectively, demonstrating satisfactory adjustment of the data to the model (Figure 3 ).

The dose that caused $50 \%$ reduction in shoot dry weight $\left(\mathrm{GR}_{50}\right)$ of the susceptible biotype was $64.7 \mathrm{~g}$ a.i. ha ${ }^{-1}$ of clethodim,

Table 1 - Values of C50 with confidence intervals (CI) and resistance factor of resistant and susceptible Lolium multiflorum biotypes, in response to the application of different clethodim doses (0,12, 24, 48, 72, 96, 144 and $192 \mathrm{~g}$ a.i. ha ${ }^{-1}$ ), evaluated at 14 and 28 days after treatment (DAT)

\begin{tabular}{|c|c|c|c|}
\hline \multirow{2}{*}{ Biotype } & \multirow{2}{*}{ 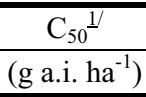 } & \multicolumn{2}{|c|}{ Resistance factor $^{2 /}$} \\
\hline & & $95 \% \mathrm{CI}$ & \\
\hline \multicolumn{4}{|c|}{14 DAT } \\
\hline $\begin{array}{l}\text { Resistant } \\
\text { Susceptible }\end{array}$ & $\begin{array}{r}159.6 \\
35.5\end{array}$ & $\begin{array}{c}143.6-175.6 \\
32.6-38.4\end{array}$ & 4.50 \\
\hline \multicolumn{4}{|c|}{28 DAT } \\
\hline $\begin{array}{l}\text { Resistant } \\
\text { Susceptible }\end{array}$ & $\begin{array}{r}172.1 \\
11.2\end{array}$ & $\begin{array}{c}169.8-174.5 \\
9.8-12.7\end{array}$ & 15.3 \\
\hline
\end{tabular}

${ }^{1 /} \mathrm{C}_{50}=$ dose required to achieve $50 \%$ control. ${ }^{2 /}$ Factor of resistance to the herbicide clethodim of Lolium multiflorum biotypes, obtained by dividing the $\mathrm{C} 50$ value of the resistant biotype by that of the susceptible biotype to clethodim. 
and that of the resistant biotype was $234.5 \mathrm{~g}$ a.i. $\mathrm{ha}^{-1}$. Considering the value of the RF (3.62), evidence was confirmed that the ryegrass biotype Cotri1 is resistant to the herbicide clethodim (Table 2). For Digitaria ciliaris biotypes resistant to ACCase inhibitors, FR values of 16.15 and 10.56 were observed for the herbicides sethoxidim and tepraloxidim, respectively (López-Ovejero et al. 2005). In the case of ryegrass resistant to clethodim, plants were harvested for assessment at 28 DAT. If the period had been longer, the RF value would have been higher, as the resistant biotype would have continued to develop normally.

The differences observed between the $\mathrm{C}_{50}$ values of the biotypes may arise from genetic

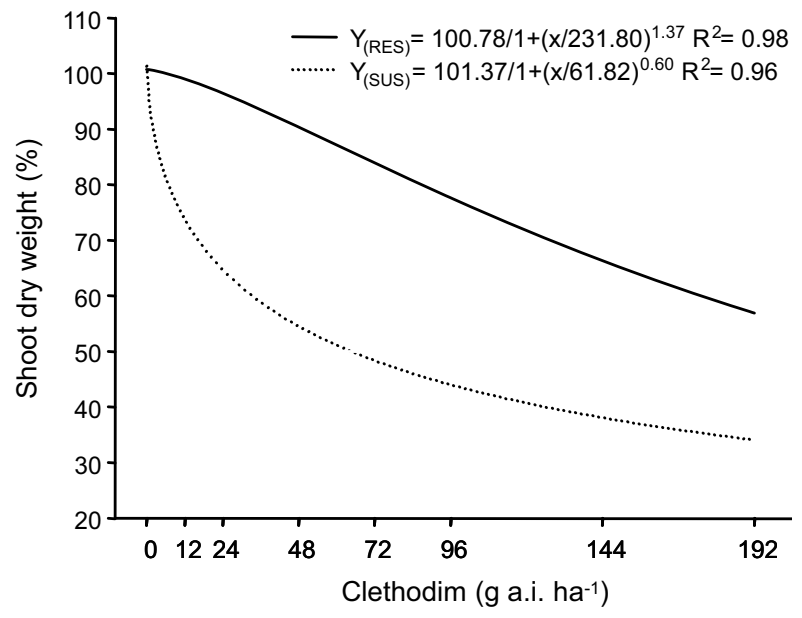

Figure 3 - Shoot dry weight (\%) of resistant and susceptible Lolium multiflorum biotypes, due to the application of different doses of the herbicide clethodim, assessed at 28 days after treatment.

Table 2 - GR50 values with confidence intervals (CI) and resistance factor of resistant and susceptible Lolium multiflorum biotypes, in response to the application of different clethodim doses $(0,12,24,48,72,96,144$ and $192 \mathrm{~g}$ a.i. ha- ${ }^{-1}$ ), evaluated at 28 days after treatment (DAT)

\begin{tabular}{|l|c|c|c|}
\hline \multirow{2}{*}{ Biotype } & $\mathrm{C}_{50^{-1}}$ & \multicolumn{2}{|c|}{ Resistance factor $^{{ }^{-/}}$} \\
\cline { 2 - 4 } & $\left(\mathrm{g} \mathrm{a.i.} \mathrm{ha}^{-1}\right)$ & $95 \%$ CI & \\
\hline Resistant & 234.5 & $219.4-249.6$ & \multirow{2}{*}{3.62} \\
Susceptible & 64.7 & $54.1-75.3$ & \\
\hline
\end{tabular}

${ }^{1 /} \mathrm{G}_{50}=$ dose required to achieve $50 \%$ reduction of dry weight. $\underline{2} /$ Factor of resistance to the herbicide clethodim of Lolium multiflorum biotypes, obtained by dividing the G50 value of the resistant biotype by that of the susceptible biotype to clethodim. traits between ryegrass biotypes, possibly influencing their responses to the herbicide clethodim. The genetic makeup of a species can determine varying degrees of resistance or susceptibility to herbicides (Hartwing et al., 2008). However, because there is no previous information about the management and genetic characterization of the species, it cannot be said that the differences in responses between the ryegrass herbicides investigated in this study are caused by these factors.

Genetic diversity is especially common among annual weeds and favors the selection of herbicide resistance. This explains, at least in part, why most biotypes worldwide which are resistant to herbicides are from annual species. Large weed infestation favors increased risk of selection for resistance (Winkler et al. 2002).

In most weeds showing resistance to inhibitors of the enzyme ACCase, this is attributed to alterations in the site of action of the enzyme (Volenberg \& Stoltenberg, 2002). However, there are reports correlating resistance to ACCase inhibitors with metabolic processes (Bravin et al. 2001). When the mechanism of resistance is due to a change in the site of action, mutations can be grouped as follows: high resistance to sethoxydim and low to other herbicides (e.g., biotypes of Setaria spp. and Avena fatua); high resistance to fluazifop-p-butyl and low resistance to other herbicides (e.g. Lolium rigidum, Eleusine indica and Alopecurus myosuroides); relatively high resistance to aryloxyphenoxypropionate (APP) and very low or no resistance to cyclohexanodione (CHD) herbicides (e.g. Lolium rigidum, Avena fatua and Lolilum multiflorum); one or more mutations give intermediate levels of resistance to both herbicide groups (e.g. Avena fatua) and high resistance to both herbicide groups (e.g. Avena fatua) (Bourgeois et al., 1997, Devine, 1997).

More studies are needed to clarify the mechanisms involved in differential response of ryegrass to ACCase inhibiting herbicides and also the possible effects of these mechanisms on the activity of other herbicides. This situation indicates that additional field experiments are needed to 
verify if environmental conditions were considered adequately. This information is essential so that management alternatives can be identified and recommended to farmers. With the information currently available, it can be stated that the ryegrass biotype known as Cotri1 is resistant to the herbicide clethodim, and it is controlled with a dose 15.3 times higher than its susceptible counterpart, and $50 \%$ reduction in dry weight of this biotype occurs with a 3.62-fold higher dose, compared to the susceptible one.

\section{LITERATURE CITED}

AVILA, L. A. et al. Assessment of acetolactate synthase (ALS) tolerance to imazethapyr in red rice ecotypes (Oryza spp) and imidazolinone tolerant/resistant rice (Oryza sativa) varieties. Pest Manag. Sci., v. 61, n. 2, p. 171-178, 2005.

BOURGEOIS, L. et al. Characterization of cross-resistance patterns in acetyl-CoA carboxylase inhibitor resitant wild oat (Avena fatua). Weed Sci., v. 45, n. 6, p. 750-755, 1997.

BRASIL. Ministério da Agricultura, Pecuária e Abastecimento. AGROFIT. Disponível em: <http:// extranet.agricultura.gov.br/agrofit_cons/ principal_agrofit_cons>.Acesso em: 7 mar. 2010.

BRAVIN, F. et al. Resistance to diclofop-methyl in two Lolium spp. populations from Italy: studies on the mechanism of resistance. Weed Res., v. 41, n. 5, p. 461-473, 2001.

CHRISTOFFOLETI, P. J. Curvas de dose-resposta de biótipos resistente e suscetível de Bidens pilosa L. aos herbicidas inibidores da ALS. Sci. Agri., v. 59, n. 3, p. 513-519, 2002.

COX, R. D.; ALLEN, E. B. Stability of exotic annual grasses following restoration efforts in southern California coastal sage shrub. J. Appl. Ecol., v. 45, n. 2, p. 495-504, 2008.

DEVINE, M. D. Mechanisms of resistance to acetylcoenzime A carboxylase inhibitors: a review. Pestic. Sci., v. 51, n. 3, p. 259-264, 1997.
FRANS, R. et al. Experimental design and techniques for measuring and analyzing plant responses to weed control practices. In: CAMPER, N. D. (Ed.). Research methods in weed science. 3.ed. Champaign: Southern Weed Science Society, 1986. 37 p.

HALL, L. M. et al. Resistance to acetolactate synthase inhibitors and quinclorac in a biotype of false clover (Gallium spurium). Weed Sci., v. 46, n. 1, p. 390-396, 1998.

HARTWING, I. et al. Tolerância de trigo (Triticum aestivum) e aveia (Avena sp.) a herbicidas inibidores da enzima acetolactato sintase (ALS). Planta Daninha, v. 26, n. 2, p. 361-368, 2008.

KISSMANN, K. G.; Plantas infestantes e nocivas. TOMO I. 3.ed. São Paulo: Basf Brasileira S. A., 2007. CD-ROM.

LÓPEZ-OVEJERO, R. F. et al. Resistência de populações de capim-colchão (Digitaria ciliaris) aos herbicidas inibidores da Acetil Co-A Carboxilase. Planta Daninha, v. 23, n. 3, p. 543-549, 2005.

POWLES, S. B.; YU, Q. Evolution in Action: Plants resistant to herbicides. Ann. Rev. Plant Biol., v. 61, n. 7, p. 317-347, 2010.

RAUCH, T. A. et al. Widespread occurrence of herbicideresistant italian ryegrass (Lolium multiflorum) in Northern Idaho and Eastern Washington. Weed Technol., v. 24, n. 3, p. 281-288, 2010.

ROMAN, E. S. et al. Resistência de azevém (Lolium multiflorum) ao herbicida glyphosate. Planta Daninha, v. 22, n. 2, p. 301-306, 2004.

SILVA, A. A.; SILVA, J. F. Tópicos em manejo de plantas daninhas. Viçosa, MG: Universidade Federal de Viçosa, 2007. 367 p.

VARGAS, L. et al. Herança da resistência de azevém (Lolium multiflorum) ao glyphosate. Planta Daninha, v. 25, n. 3, p. 567-571, 2007.

VOLENBERG, D.; STOLTENBERG, D. Altered acetylcoenzyme A carboxylase confers resistance to clethodim, fluazifop and sethoxydim in Setaria faberi and Digitaria sanguinalis. Weed Res., v. 42, n. 5, p. 342-350, 2002.

WINKLER, L. M. et al. Aspectos genéticos envolvidos na resistência de plantas daninhas aos herbicidas. R. Plantio Direto, v. 70, n. 4, p. 21-24, 2002. 